\title{
Optimum dietary protein requirement for Amazonian Tambaqui, Colossoma macropomum Cuvier, 1818, fed fish meal free diets
}

\begin{abstract}
César Augusto OISHI ${ }^{1}$; Lawrence C. NWANNA²; Manoel PEREIRA FILHO ${ }^{3}$
ABSTRACT

Fish meal free diets were formulated to contain graded protein levels as 25\% (diet 1), 30\% (diet 2), 35\% (diet 3) and 40\% (diet 4). The diets were fed to tambaqui juveniles (Colossoma macropomum) $(46.4 \pm 6.3 \mathrm{~g}$ ) in randomly designed recirculating systems for 60 days, to determine the optimum protein requirement for the fish. The final weight of the fish, weight gain (28.1, $28.5,32.2,28.0 \mathrm{~g})$ and specific growth rate increased $(\mathrm{P}>0.05)$ consistently with increasing dietary protein up to treatment with $35 \%$ protein diet and then showed a declining trend. Feed intake followed the same trend resulting in best feed efficiency $(62.5 \%)$ in fish fed diet with $35 \%$ protein. Similarly, the protein intake increased significantly with increasing dietary protein levels and reduced after the fish fed with $35 \%$ protein; while protein efficiency ratio $(2.28,1.99,1.87,1.74)$ decreased with increasing dietary protein levels. Carcass ash and protein had linear relationship with dietary protein levels while the lipid showed a decreasing trend. Ammonia content $\left(0.68,0.73,0.81,1.21 \mathrm{mg} \mathrm{L}^{-1}\right)$ of the experimental waters also increased $(\mathrm{P}<0.05)$ with increasing protein levels while $\mathrm{pH}$, dissolved oxygen and temperature remained fairly constant without any clear pattern of inclination. Broken-line estimation of the weight gain indicated 30\% protein as the optimum requirement for the fish.
\end{abstract}

KEYWORDS: Tambaqui, protein requirement, fish meal free diets

\section{Exigência protéica de juvenis de tambaqui, Colossoma macropomum Cuvier, 1818, alimentados com rações livres de farinha de peixe}

\begin{abstract}
RESUMO
Foram formuladas quatro dietas sem a inclusāo de farinha de peixes contendo os níveis crescentes de proteína de $25 \%$ (dieta 1), 30\% (dieta 2), 35\% (dieta 3) e 40\% (dieta 4). As dietas foram fornecidas a juvenis de tambaqui (Colossoma macropomum) $(46.4 \pm 6.3 \mathrm{~g})$ distribuídos ao acaso em um sistema de recirculação durante 60 dias, para determinar o requerimento protéico ótimo para o peixe nesta faixa etária. O peso final dos peixes, o ganho de peso $(28.1,28.5,32.2,28.0 \mathrm{~g})$ e a taxa de crescimento específico tiveram um aumento não significativo $(P>0,05)$ conforme aumentou o nível protéico das raçôes até o nível de $35 \%$ proteína e entáo uma tendência ao declínio. O consumo de alimento seguiu a mesma tendência resultando em melhor eficiência alimentar (62.5\%) para os peixes alimentados com a dieta contendo $35 \%$ de proteína. Similarmente, o consume de proteína aumentou significativamente com o aumento crescente dos níveis protéicos dietários e reduziu após os peixes serem alimentados com a dieta com $35 \%$ de proteína, enquanto a taxa de eficiência protéica $(2.28,1.99,1.87,1.74)$ diminuiu com o aumento dos níveis protéicos dietários. A cinza e a proteína da carcaça apresentaram uma relação linear com os níveis protéicos dietários enquanto o lipídio mostrou uma tendência decrescente. $\mathrm{O}$ aumento do conteúdo da amônia $(0.68,0.73,0.81,1.21$ mg L-1) da água dos tanques experimentais com a elevação dos níveis de proteína não foi significativo $(P>0,05)$ enquanto o $\mathrm{pH}$, oxigênio dissolvido e a temperatura permaneceram claramente constantes sem qualquer padrão claro de inclinação. $\mathrm{O}$ "ponto de virada" da curva de ganho de peso indicou 30\% como o nível protéico ótimo para esta espécie de peixe, nesta fase de crescimento, nas condiçôes deste experimento.
\end{abstract}

PALAVRAS-CHAVE: Tambaqui, requerimento protéico, dietas sem farinha de peixe

\footnotetext{
1, 3 Instituto Nacional de Pesquisas da Amazônia, Coordenação de Pesquisas em Aquicultura, Laboratório de Nutrição de Peixes. Av. André Araújo, 2936 , Petrópolis $69060-001$ Manaus, AM - Brasil. Email: oishi@inpa.gov.br, pmanoel@inpa.gov.br

2 Department of Fisheries and Wildlife, Federal University of Technology, Akure, Nigeria, drlu2001@yahoo.com
} 


\section{INTRODUCTION}

Fish feed constitutes over $60 \%$ of the operating cost of aquaculture (Nwanna 2002). Yang et al. (2002) similarly described that fish feed accounts for $50 \%$ or more of the total production cost. Out of this cost, protein takes about 75\% (Nwanna and Fashae 2008) confirming it as the single most expensive component of fish feeds (NRC 1993; De Silva and Anderson 1995). Thus knowledge of the protein requirement is important for the formulation of well-balanced and low cost feeds (Shiau and Lan 1996). Careless waste of dietary protein due to non-quantification of accurate protein requirements in fish could lead to drastic reduction or negative returns to investment, and should be avoided.

Apart from the economic significance of using optimum protein levels in fish nutrition, it results in low pollution of the fish culture environment especially in intensive fish farming or in recirculatory aquaculture systems. The end product of protein metabolism in fish is ammonia and significant nitrogenous waste products (Wood 1993), therefore, measurement of ammonia and urea excretion have been used as indicators of the effects of protein metabolism on the various environmental and nutritional factors and insight into the nitrogen balance of fish (Perera et al. 1995). Engin and Carter (2001) reported that excess supply of protein to Australian short-finned eel (Anguilla australis) resulted in significantly daily ammonia and urea-nitrogen excretion. Accumulation of nitrogenous excretory products can cause deterioration of water quality in a recirculating culture system (Engin and Carter 2001) and fish ponds (Yoshida 2000). Therefore, quantification of dietary protein requirements for fish is of significant importance to reduce or limit water quality deterioration in culture environments from protein related waste product.

Tambaqui, Colossoma macropomum, is a popular food fish of the Amazon basin, well known in Amazon forest countries like Brazil, Colombia, Peru and Venezuela (Araujo-Lima and Goulding 1998), because of its fast growth, big size and tolerance to low water quality and disease (Saint-Paul 1986). Adequate dietary protein promotes good growth rates and feed utilization without causing excessive accumulation of lipid in the liver (Dos Santos et al. 1993). However, information on the protein requirements of tambaqui is sparce. Most of the studies on tambaqui have concentrated on the growth performance of the fish under culture conditions (Oishi 2007). A study using fish meal reported the protein requirement of tambaqui (30-250g) as 25.01g (Vidal Jr. et al., 1998), but no literature has reported the protein requirement of the fish using non-fish meal diets. In the face of dwindling capture fisheries production and supply of low quality fish meal at expensive prizes, there is a strong need for research into alternative protein ingredients. Therefore this study investigated the effects of different levels of fish meal free diets on the growth and nutrient utilization of juveniles tambaqui with a view to determining the optimum protein requirement for the fish. The results were also compared with other studies that used fish meal.

\section{MATERIALS AND METHODS}

\section{Diets preparation}

Four fish meal free diets were formulated to contain graded levels of protein as $25 \%(\mathrm{D} 1), 30 \%(\mathrm{D} 2), 35 \%$ (D3) and $40 \%(\mathrm{D} 4)$. The sources of protein were soybean meal and rendered animal by-product (bone and meat meal). All dried ingredients (Table 1) were mixed thoroughly before pelleting. Gross energy of the diets was calculated using (kcal $\left.100 \mathrm{~g}^{-1}\right)$ values of 5.64, 9.11 and 4.11 for protein, lipid and carbohydrate (NRC 1993).

Table 1 - Gross and proximate composition of experimental diets ( $\left.100 \mathrm{~g}^{-1} \mathrm{DM}\right)$

\begin{tabular}{lcccc}
\hline & Diet 1 & Diet 2 & Diet 3 & Diet 4 \\
\cline { 2 - 5 } & $25 \% \mathrm{CP}^{1}$ & $30 \% \mathrm{CP}$ & $35 \% \mathrm{CP}$ & $40 \% \mathrm{CP}$ \\
\hline Ingredients & & & & \\
Soybean meal (49.9\% CP) & 15.0 & 19.0 & 23.0 & 27.0 \\
\hline Maize gluten (69.0\% CP) & 8.00 & 13.0 & 18.0 & 23.0 \\
\hline Meat/bone meal (52.7\% CP) & 8.00 & 10.0 & 12.0 & 14.0 \\
Wheat flour (17.8\% CP) & 20.0 & 15.0 & 10.0 & 5.20 \\
Maize (9.1\% CP) & 40.2 & 34.2 & 28.1 & 22.0 \\
\hline Wheat bran (9.3\% CP) & 7.00 & 7.00 & 7.00 & 7.00 \\
\hline Vitamin-mineral premix & 1.00 & 1.00 & 1.00 & 1.00 \\
\hline Methionine & 0.20 & 0.20 & 0.20 & 0.20 \\
\hline Lysine & 0.60 & 0.60 & 0.60 & 0.60 \\
\hline Proximate composition (\%) & & & & \\
\hline Dry matter & 92.3 & 91.3 & 92.1 & 93.0 \\
\hline Ash & 6.70 & 6.90 & 8.00 & 7.90 \\
\hline Lipid & 2.00 & 2.20 & 2.50 & 1.90 \\
\hline Fibre & 4.59 & 4.41 & 4.23 & 4.05 \\
\hline Protein & 27.8 & 32.0 & 36.6 & 39.7 \\
\hline Carbohydrate & 51.2 & 45.8 & 40.8 & 39.5 \\
\hline Gross energy (kcal/100g) & 386.1 & 389.4 & 397.6 & 404.0 \\
\hline P: E ratio & 13.9 & 12.2 & 10.9 & 10.2 \\
\hline
\end{tabular}

1. Crude protein

${ }^{2} \mathrm{~kg}^{-1}$ diet: Calcium 4.5\%; phosphorus 0.5\%; copper 2.66mg; iron 6.66mg; iodine $0.25 \mathrm{mg}$; manganese $25 \mathrm{mg}$; zinc $16.6 \mathrm{mg}$; vitamin A $3.33 \mathrm{UI}$; vit. E 2UI; vit. C 1,000ppm; vit. D3 800Ul; Vit. B $0.46 \mathrm{mg}$; vit. B12 3.33mg;

vit. B2 1.66mg; vit. K $0.52 \mathrm{mg}$

\section{Feeding experiment}

The experiment was conducted at the Instituto Nacional de Pesquisas da Amazonia (INPA) Manaus, Brazil. Sixteen cylindrical fibre glass tanks of $200 \mathrm{~L}$ water capacity were used for the feeding trials with fish of mean weight $(46.4 \pm 6.3 \mathrm{~g})$. 
There were four treatments and each was in four replicates. Water flow into the tanks was adjusted at $1.5 \mathrm{~L}$ per minute. Air stones were used to aerate the tanks throughout the feeding period. About 400 juveniles of Tambaqui were harvested from the Instituto Nacional de Pesquisas da Amazonia (INPA) fish farm and acclimatized for one month before the experiment. Then 320 fish of uniform sizes $(46.4 \pm 6.3 \mathrm{~g})$ were weighed individually and grouped into 20 fish per tank according to the four treatments. The fish were fed to satiation twice daily between 08.00 and 10.00 and 16.00 and $18.00 \mathrm{~h}$ six days a week, for 60 days. Weight of the fish was measured bi-weekly and used to calculate the weight gain, specific growth rate $(S G R)$ and feed conversion ratio. Weight gain $=$ final weight - initial weight, $S G R=100 \times\left(\log _{e}\right.$ final weight- $\log _{e}$ initial weight $/$ culture period (days). Protein intake $(\%)=$ Protein $(\%)$ in diet $\mathrm{x}$ total diet consumed $(\mathrm{g}) / 100$. Feed conversion ratio $=$ weight of feed fed (g)/fish weight gain. Protein efficiency ratio (PER) was calculated as weight gain $\mathrm{x} 100 /$ protein intake.

\section{Water quality analysis and measurement}

The dissolved oxygen, temperature, conductivity and $\mathrm{pH}$ of the experimental tank waters were measured daily, while ammonia content of the water was measured bi-weekly. Dissolved oxygen was measured by combined digital oxygen, conductivity, salinity and temperature Meter YSI 85 (YSI incorporated Yellow Springs, Ohio USA), while $\mathrm{pH}$ and Temperature were measured by combined digital $\mathrm{pH}$ and Temperature Meter YSI 60. The ammonia concentration was determined based on the formation as a result of substitution of indophenol for sodium salicylate as phenolic reagent (Verdouw et al. 1978).

\section{Analytical methods}

The proximate analyses of the feed and fish samples were carried out following the methods of AOAC (1995). Broken line estimation was done according to methods of Robbins et al. (2006)

Data were subjected to one way analysis of variance (ANOVA) using SAS/SAT Institute Software (1998). Duncan multiple range test was used to separate means among treatments at $(\mathrm{P}=0.05)$ (Duncan 1955).

\section{RESULTS}

The proximate composition of the experimental diets (Table 1) showed that the dry matter, ash, lipid and protein contents of the diets were closely related. There was also increment in the protein content due to increasing dietary protein levels. Carbohydrate content and protein energy ratio of the diets were highest in those with-lowest protein level and showed a decreasing trend towards the diets with higher protein levels, while the energy content of the diets increased with increasing dietary protein levels. This is an indication that more energy may be provided by dietary protein than the carbohydrate.

Table 2 presents the growth and nutrient utilization of tambaqui that were fed graded protein diets. There was general increase in the final weight of the fish, weight gain, specific growth rate, feed intake and protein intake resulting from increasing dietary protein levels up 35\% and then a decline. While there were no significant differences in the growth parameters, the feed consumed by fish fed diet with $35 \%$ protein was significantly higher than that consumed by the fish fed diet with $40 \%$ protein. This may suggest that adequate dietary protein may stimulate appetite. The fish fed diet with 35\% protein also had the best feed conversion ratio and highest feed efficiency. Protein intake was highest in fish fed diet with 35\% protein and reduced in fish fed $40 \%$ protein diet. Protein efficiency ratio was significantly highest in fish fed 25\% protein diet and least in fish fed 40\% protein diet, indicating a decreasing trend with increasing dietary protein levels. It is interesting to note that while increasing levels of dietary protein resulted in increasing protein intake, it led to decreasing protein efficiency ratio. The table also indicated that the fish can thrive well with dietary protein levels of $25-35 \%$, but the broken-line estimation of the weight gain (Fig. 1) indicated $30 \%$ protein as the optimum protein requirement for the fish.

Table 2 - Growth and nutrient utilization of tambaqui fed graded protein diets

\begin{tabular}{|c|c|c|c|c|}
\hline & Diet 1 & Diet 2 & Diet 3 & Diet 4 \\
\hline & $25 \%$ CP & $30 \%$ CP & $35 \%$ CP & $40 \% \mathrm{CP}$ \\
\hline Final mean Wt. (g) & $74.5^{\mathrm{a}} \pm 1.39$ & $74.9^{\mathrm{a}} \pm 2.89$ & $78.6^{\mathrm{a}} \pm 4.49$ & $73.8^{\mathrm{a}} \pm 1.00$ \\
\hline Initial mean Wt. (g) & $46.4^{\mathrm{a}} \pm 0.40$ & $46.4^{a} \pm 0.35$ & $46.3^{a} \pm 0.39$ & $45.8^{a} \pm 0.26$ \\
\hline Weight gain (g) & $28.1^{\mathrm{a}} \pm 1.20$ & $28.5^{\mathrm{a}} \pm 2.69$ & $32.2^{\mathrm{a}} \pm 4.45$ & $28.0^{\mathrm{a}} \pm 1.20$ \\
\hline $\begin{array}{l}\text { Specific growth rate } \\
\left(\% \text { day }^{-1}\right)\end{array}$ & $0.80^{\mathrm{a}} \pm 0.00$ & $0.80^{\mathrm{a}} \pm 0.01$ & $0.90^{\mathrm{a}} \pm 0.01$ & $0.80^{\mathrm{a}} \pm 0.00$ \\
\hline Feed intake fish-1 & $47.9^{\mathrm{ab}} \pm 4.60$ & $49.0^{\mathrm{ab}} \pm 2.76$ & $51.0^{\mathrm{b}} \pm 1.27$ & $43.6^{\mathrm{a}} \pm 1.38$ \\
\hline Feed conversion ratio & $1.70^{\mathrm{a}} \pm 0.10$ & $1.70^{\mathrm{a}} \pm 0.10$ & $1.60^{\mathrm{a}} \pm 0.20$ & $1.62^{\mathrm{a}} \pm 0.10$ \\
\hline Protein intake fish ${ }^{-1}$ & $12.3^{\mathrm{a}} \pm 0.40$ & $14.3^{b} \pm 1.30$ & $17.2^{c} \pm 0.90$ & $16.1^{b c} \pm 0.50$ \\
\hline Protein efficiency ratio & $2.28^{b} \pm 0.10$ & $1.99^{\mathrm{a}} \pm 0.20$ & $1.87^{\mathrm{a}} \pm 0.20$ & $1.74^{\mathrm{a}} \pm 0.10$ \\
\hline
\end{tabular}

Means of 4 values in a row with similar superscripts are not significant $(P>0.05)$

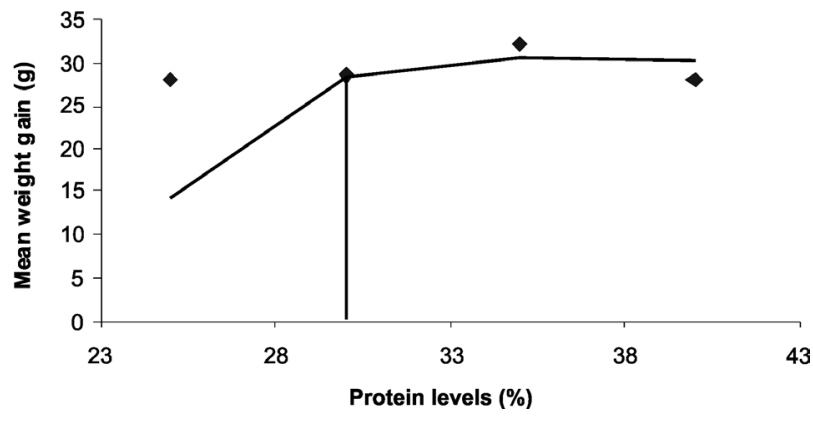

Figure 1 - Estimation of protein requirement by broken-line analysis 
Carcass composition of tambaqui fed graded protein diets is shown in Table 3. Generally, the dry matter, ash and protein content of the initial sample were significantly higher than the values after feeding the fish with experimental diets, while the lipid was significantly lower. The dry matter of the fish fed diets with different levels of protein was statistically the same and showed no definite trend of inclination. The ash content of the fish was also statistically the same but showed an increasing trend with increasing dietary protein levels. Lipid content was significantly highest in fish fed diet with least protein level and decreased with increasing dietary protein levels, that fish fed diet with the highest protein content retained the lowest amount of lipid. The protein content of the fish was statistically similar but increased with increasing dietary protein levels.

Table 3 - Carcass composition of tambaqui fed graded protein diets

\begin{tabular}{cccccc}
\hline \multirow{2}{*}{ Initial } & Diet 1 & Diet 2 & Diet 3 & Diet 4 \\
\cline { 3 - 6 } & $25 \% \mathrm{CP}^{1}$ & $30 \% \mathrm{CP}$ & $35 \% \mathrm{CP}$ & $40 \% \mathrm{CP}$ \\
\hline Dry matter & $96.2^{\mathrm{b}} \pm 0.08$ & $91.2^{\mathrm{a}} \pm 0.86$ & $91.4^{\mathrm{a}} \pm 0.91$ & $91.3^{\mathrm{a}} \pm 1.18$ & $90.6^{\mathrm{a}} \pm 1.31$ \\
Ash & $20.0^{\mathrm{b}} \pm 0.90$ & $13.3^{\mathrm{a}} \pm 1.24$ & $13.8^{\mathrm{a}} \pm 0.88$ & $13.5^{\mathrm{a}} \pm 1.05$ & $14.3^{\mathrm{a}} \pm 0.57$ \\
Lipid & $10.4^{\mathrm{a}} \pm 0.59$ & $26.9^{\mathrm{d}} \pm 0.77$ & $24.2^{\mathrm{c}} \pm 0.26$ & $25.8^{\text {cd }} \pm 1.35$ & $22.7^{\mathrm{b}} \pm 1.18$ \\
Protein & $67.9^{\mathrm{b}} \pm 0.71$ & $51.2^{\mathrm{a}} \pm 1.53$ & $52.5^{\mathrm{a}} \pm 1.30$ & $53.1^{\mathrm{a}} \pm 1.32$ & $54.4^{\mathrm{a}} \pm 2.38$ \\
\hline
\end{tabular}

Means of 4 values in a row with similar superscripts are not significant $(P>0.05)$

Physical and chemical properties of the water used in fish culture are presented in Table 4. Dietary protein levels did not affect the water quality hence there was no significant differences in the mean temperature, dissolved oxygen, conductivity and $\mathrm{pH}$ of the culture media. Temperature ranged 27 and $27.1^{\circ} \mathrm{C}$, dissolved oxygen between 6.57 and $6.96 \mathrm{mg} / \mathrm{l}$, conductivity between 22.4 and $\left.24.0(\mu \mathrm{ohm} \mathrm{sec})^{-1}\right)$. The $\mathrm{pH}$ was in the acidic range of 5.09 and 5.19, indicating higher affinity of the fish to acidic media. Ammonia concentration (Fig. 2) also increased with increasing levels of dietary protein suggesting the effect of metabolism of amino acids from dietary proteins and the release of nitrogenous compounds.

Table 4- Parameters of water for culturing tambaqui fed graded protein diets

\begin{tabular}{ccccc}
\hline & Diet 1 & Diet 2 & Diet 3 & Diet 4 \\
\cline { 2 - 5 } & $25 \% \mathrm{CP}^{1}$ & $30 \% \mathrm{CP}$ & $35 \% \mathrm{CP}$ & $40 \% \mathrm{CP}$ \\
\hline Temperature $\left({ }^{\circ} \mathrm{C}\right)$ & $27.0 \pm 0.15$ & $27.1 \pm 0.06$ & $27.1 \pm 0.10$ & $27.0 \pm 0.03$ \\
Dissolved oxygen $\left(\mathrm{mg} \mathrm{L}^{-1}\right)$ & $6.68 \pm 0.27$ & $6.96 \pm 0.13$ & $6.57 \pm 0.41$ & $6.69 \pm 0.20$ \\
Conductivity $\left(\mu \mathrm{S} \mathrm{cm}^{-1}\right)$ & $22.9 \pm 1.08$ & $22.4 \pm 1.46$ & $22.5 \pm 1.44$ & $24.0 \pm 0.85$ \\
$\mathrm{pH}$ & $5.09 \pm 0.10$ & $5.19 \pm 0.34$ & $5.13 \pm 0.16$ & $5.16 \pm 0.15$ \\
\hline
\end{tabular}

Means of 4 values in a row with similar superscripts are not significant $(P>0.05)$

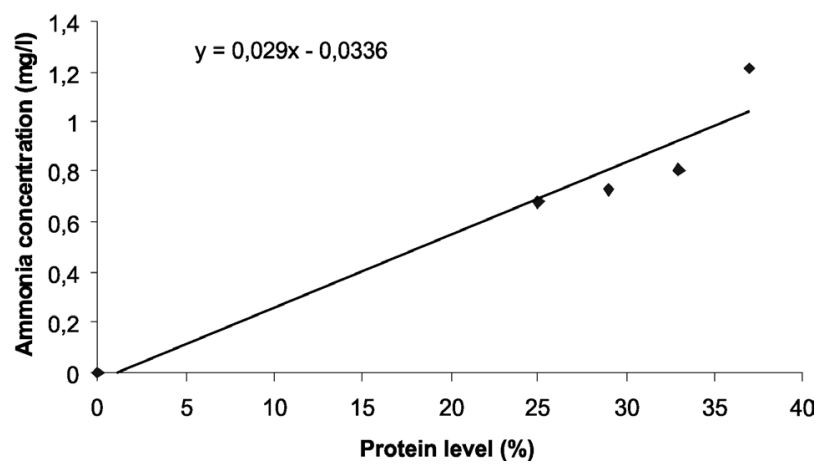

Figure 2 - Effect of protein levels on ammonia concentration in water

\section{DISCUSSION}

The results showed that growth performance of the fish increased with increasing dietary protein level to a point and then declined with further increase. Increasing dietary protein resulted in improvement in protein intake, feed conversion ratio and feed efficiency to a limit and declined. Shiau and Lan (1996) reported similar observation with feed efficiency for grouper fed different dietary protein diets. This observation is in line with the reports of (Mohanty and Samantaray 1996; Gunasekera et al. 2000). Similar trend was also reported by Yang et al. (2002) for juvenile silver perch fed graded levels of dietary protein.

In the present study, optimum protein requirement of $30 \%$ was obtained contrary to $25.01 \%$ and $25 \%$ respectively reported for the same size of fish species by Vidal Jr. (1998) and Mori-Pinedo (1999). This discrepancy could be attributed to dietary ingredient combinations, because while the previous studies used a combination of fish meal and soybean meal for dietary protein sources, the present study did not use fish meal. Allan (1995) suggested that when both fish meal and soybean meal are used in diets, that the protein requirement of a fish could be less than when only soybean meal is used. Shiau and Lan (1996) also reported that different protein sources can affect the protein requirement of a fish. However, it is interesting to note that the growth, feed efficiency and protein efficiency ratio of the fish fed combined fish meal and soybean meal compare very well with the values obtained from feeding the fish with only soybean meal, an indication that soybean meal alone could meet the protein need of the fish, judging by $30-55 \%$ protein requirements for fishes (NRC 1993). This supports the fish as ominivorous herbivore that feeds very low in the food chain, and therefore may require more of plant feedstuffs than animal protein.

Diets with less protein had higher levels of carbohydrates and conversely, that higher protein diets had lower percentages of carbohydrates. Cho and Kaushik (1985) and Engin and Carter (2001) opined that an increase in the dietary level of 
nonprotein digestible energy increased nitrogen retention by decreasing nitrogen losses. According to Shimeno et al. (1981), increasing dietary carbohydrate and fat caused a reduction in the activities of amino acid-degrading enzymes in the hepatopancreas and resulted in a low nitrogen excretion rate and a high protein efficiency ratio.

The study also indicated that feed efficiency and protein efficiency ratio improved as protein/energy ratio of the diets decreased. This is in line with the report of Mathis et al. (2003) that feed efficiency and protein efficiency ratio of Eurasian perch improved with decreasing values of protein/energy ratios. This is an indication that the best growth performance of the fish in relation to protein level should be achieved by the determination of appropriate/optimum protein-energy ratio using the same feeds combination.

In the present study, carcass ash and protein contents of tambaqui fed graded protein diets were positively correlated with dietary protein levels, while the lipid content of the fish had inverse relationship with dietary protein levels. Similar results on carcass body protein of other species of fish have been reported (Gunasekera et al., 2000). The observed inverse relationship between the carcass lipid and dietary protein levels has also been noted with other fish species (Khan et al. 1993; Chen and Tsai 1994; Arzel et al. 1995; Yang et al. 2002). However, this observation is in contrast with that of Shiau and Lan (1996) who reported positive correlation between carcass lipid of grouper (Epinephelus malabaricus) and dietary protein levels. They also opined that differences in carcass lipid content might be attributed to differences in the dietary carbohydrates as fish differ in their ability to utilize carbohydrates. Shiau and Lin (1993) similarly reported higher body lipid in tilapia fed starch diets than the fish fed glucose diets.

Dietary protein levels did not significantly affect the water quality of the culture media, as the values were fairly constant without clear pattern of inclination. However, ammonia content of the water increased proportionately with increasing dietary protein levels, a trend consistent with the observation of Yang et al. (2002). The trend is also in consonance with previous reports for eels. Kaushik and Cowey (1990) similarly described that ammonia excretion rates are directly related to dietary nitrogen content and protein intake. Accumulation of nitrogenous excretory products can cause deterioration in water quality (Engin and Carter, 2001) because most of the nitrogen excreted is derived from deamination of amino acids from dietary proteins (Wood 1993; Brunty et al. 1997).

\section{CONCLUSION}

The study established optimum dietary protein requirement of tambaqui $(46.4 \pm 6.3 \mathrm{~g})$ as $30 \%$ using fish meal free diets; suggesting that only soybean meal and rendered animal by product (meat/bone meal) could meet the protein needs of the fish.

\section{ACKNOWLEDGEMENTS}

The authors are very grateful to Fundaçáo de Amparo à Pesquisa do Estado do Amazonas (FAPEAM) and Conselho Nacional do Desenvolvimento Cientifico e Tecnológico (CNPq) Brazil for financial support and Maria Ines de Oliveira Pereira for chemical analyses of the samples.

\section{LITERATURE CITED}

A.O.A.C. (Association of Official Analytical Chemists - A.O.A.C). 1995. Official methods of analysis. $12^{\text {th }}$ Edition. George Banta Co. Inc. Manasha, Winsconsin, USA. 937 p.

Araujo-Lima, C.; Goulding, M. 1998. Os frutos do tambaqui: ecologia, conservação e cultivo na Amazônia. Sociedade Civil Mamirauál CNPq. Tefe, AM. 187 p.

Arzel, J.; Metailler R.; Kerleguer, C.; Le Delliou, H.; Guilaume, J. 1995. The protein requirement of brown trout (Salmo trutta) fry. Aquaculture, 130: 67-78.

Brunty, J.L.; Bucklin, R.A.; Davis, J.; Baird, C.D.; Nordstedt, R.A. 1997. The influence of feed protein intake on tilapia ammonia production. Aquaculture Engineering, 16: 161-166.

Carvalho, M.L. 1981. Alimentação do tambaqui jovem (Colossoma macropomum Cuvier, 1818) e sua relação com a comunidade zooplanctônica do lago Grande-Manaquiri, Solimöes- $A M$. Master's Thesis, Fundaçáo Universidade do Amazonas, Instituto Nacional de Pesquisas da Amazônia, Manaus, Brazil. 90 p.

Chen, H.Y.; Tsai, J.C. 1994. Optimal dietary protein level for the growth of juvenile grouper, Epinephelus malabaricus, fed semipurified diets. Aquaculture, 119: 265-271.

Cho, C.Y.; Kaushik, S.J. 1985. Effects of protein intake on metabolizable and net energy values of fish diets. In: Cowey, C.B., Mackie, A.M., Bell, J.G (Eds.), Nutrition and Feeding in Fish. Academic Press, London, p.95-117.

Daniels, W.H.; Robinson, E.H. 1986. Protein and energy requirements of juvenile red drum (Sciaenops ocellatus). Aquaculture, 53: 243-252.

De Silva, S. S.; Anderson, T.A. 1995. Fish Nutrition in Aquaculture. Chapman \& Hall, London, UK, 319 pp.

Dos Santos, J.; Burkow, I.C.; Jobling, M. 1993. Patterns of growth and lipid deposition in cod (Gadus morhua L) fed natural prey and fish-based feeds. Aquaculture, 110: 173-189.

Duncan, D.B. 1955. Multiple F-test. Biometrics 11:1-42.

Engin, K.; Carter, C.G. 2001. Ammonia and urea excretion rates of juvenile Australian short-finned eel (Anguilla australis) as influenced by dietary protein level. Aquaculture, 194: 123-136.

Goulding, M. 1980. The fishes and the forest. Exploration in Amazonian natural history. University of Carlifonia Press, Berkeley, CA, 280 p. 
Gunasekera, R.M.; De Silva, S.S.; Collins, R.A.; Gooley, G.; Ingram, B.A. 2000. Effect of dietary protein level on growth and food utilization in juvenile Murray cod Maccullochella peelii (Mitchell). Aquaculture Research, 31: 181-187.

Hidalgo, F.; Alliot, E. 1988. Influence of water temperature on protein requirement and protein utilization in juvenile sea bass, Dicentrachus labrax. Aquaculture, 72: 115-129.

Jobling, M.; Wandsvik, A. 1983. Quantitative protein requirements of Artic charr, Salvelinus alpinus (L). Journal of Fish Biology, 22:705-712.

Khan, C.; Ang, K.J.; Ambak, M.A.; Saad, C.R. 1993. Optimum dietary protein requirement of a Malaysian freshwater catfish, Mystus nemurus. Aquaculture, 112: 227-235

Kim, K.; Kayes, T.B.; Amundson, C.H. 1991. Purified diet development and re-evaluation of the dietary protein requirement of fingerlings rainbow trout (Oncorhynchus mykiss). Aquaculture, 96: 57-67.

Kaushik, S.J.; Cowey, C.B. 1990. Dietary factors affecting nitrogen excretion by fish. In: Cowey, C.B.; Cho, C.Y. (Eds). Nutritional Strategies and Aquaculture Waste, Proceedings of the First International Symposium on Nutritional Strategies in Management of Aquaculture Waste, Ontario, 5-8 June, University of Guelph, Canada. p. 3-19.

Mathis, N.; Feidt, C.; Brun-Bellut, J. 2003. Influence of protein/ energy ratio on carcass quality during the growing period of Eurasian perch (Perca fluviatilis) Aquaculture, 217: 453-464.

Mohanty, S.S.; K. Samantaray, K. 1996. Effect of varying levels of dietary protein on the growth performance and feed conversion efficiency of snakehead Channa striata fry. Aquaculture Nutrition, 2: 89-94.

Mori-Pinedo, L.A. 1999. Determinação das exigências protéicocalóricas de alevinos de tambaqui Colossoma macropomum, cuvier 1818 (pisces, serrasalmidae) Master's Thesis, Instituto Nacional de Pesquisas da Amazônia - INPA Universidade do Amazonas, Manaus, Amazonas. 152p.

N.R.C. (National Research Council - N.R.C.). 1993. Nutritional Requirements of Fishes. National Academy Press. Washington, DC, USA. 114 p.

Nwanna, L.C. 2002. Performance of hybrid clariid catfish fingerlings (male Heterobranchus Bidorsalis $x$ female Clarias gariepinus) fed poultry layer waste diets in glass tanks. Journal of Applied Aquaculture, 12(3): 99-106

Nwanna, L. C.; Fashae, O.F. 2008. Use of discarded cocoa bean meal as a source of dietary energy for the production of African catfish (Clarias gariepinus, Burchell 1822). World Aquaculture (in press)
Oishi, C. A. 2007. Residuo da Castanha da Amazônia (Bertholletia excelsa) como ingrediente em raçôes para juvenis de tambaqui (Colossoma macropomum). Master's Thesis, Instituto Nacional de Pesquisas da Amazônia - INPA, 76p

Perera, W.M.K.; Carter, C.G.; Houlihan, D.F. 1995. Feed consumption, growth and growth efficiency of rainbow trout, Oncorhynchus mykiss (Walbaum) fed diets containing bacterial single cell protein. British Journal of Nutrition, 73: 591-603.

Robbins, K.R.; Saxton, A.M.; Southern, L.L. 2006. Estimation of nutrient requirements using broken-line regression analysis. Journal Animal Science, 84E E155-E165.

Saint-Paul, U. 1986. Potential for aquaculture of South American freshwater fishes: a review. Aquaculture, 54: 205-40.

SAS. 1998. SAS/STAT Software. User's guide Release 6.03. SAS Institute Inc., Cary NC, 956p

Shiau, S.Y.; Lan, C.W. 1996. Optimum dietary protein level and protein to energy ratio for growth of grouper (Epinephelus malabaricus). Aquaculture, 145: 259-266.

Shimeno, S.; Takeda, M.; Takayama, S., Sasaki, H. 1981. Response of nitrogen excretion to change of dietary composition in carp. Bulletin of the Japanese Society for the Science of Fish, 47: 191-195.

Shiau, S.Y.; Lin, S.F. 1993. Effect of supplemental dietary chromium and vanadium on the utilization of different carbohydrates in tilapia, Oreochromis niloticus x O. aureus. Aquaculture, 110: 321-330.

Verdouw, H.; Van Echteld, C. J. A.; Dekkers, E. M. J. 1978. Ammonia determination based on indophenol formation with sodium salicylate. Water Research, 12 (6): 399-402.

Vidal Jr. M.V.; Donzele, J.L.; da Silva Camargo, A.C.; de Andrade, D.R.; dos Santos, L.C. 1998. Níveis de proteína bruta para tambaqui (Colossoma macropomum), na fase de 30 a 250 gramas. 1. Desempenho dos tambaquis. Revista Brasileira de Zootecnia, 27: 421-426.

Wood, C. M. 1993. Ammonia and urea metabolism and excretion. In: Evans, D. H. (Ed). Physiology of Fishes. CRC Press, Boca, p. 379-425.

Yang, S. D.; Liou, C.H.; Liu, F.G. 2002. Effects of dietary protein level on growth performance, carcass composition and ammonia excretion in juvenile silver perch (Bidyanus bidyanus). Aquaculture, 213: 363-372

Recebido em 26/11/2008

Aceito em 03/03/2010 